\title{
Peer Effects and Scholastic Achievement: Regression Discontinuity Estimates Using the Age Sorting Criterion in the Composition of Classrooms
}

\author{
Isabel Pessoa de Arruda Raposo ${ }^{1}$, Sammara Cavalcanti Soares ${ }^{2}$, Tatiane Almeida de Menezes ${ }^{3}$ \\ ${ }^{1}$ Center for Studies on Social Statistics, Fundação Joaquim Nabuco, Ministry of Education, Brazil \\ ${ }^{2}$ Phd graduate in São Paulo School of economics (FGV-EESP) \\ ${ }^{3}$ Economics Department, Federal University of Pernambuco, Brazil (UFPE) \\ Correspondence: Isabel Pessoa de Arruda Raposo, Fundação Joaquim Nabuco, Rua Dois Irmãos, 92 - Ed. Anexo Anízio \\ Teixeira - Apipucos, Recife/PE - Brazil.
}

Received: June 11, $2018 \quad$ Accepted: July 4, $2018 \quad$ Online Published: July 9, 2018

doi:10.11114/jets.v6i9.3424 URL: https://doi.org/10.11114/jets.v6i9.3424

\begin{abstract}
This paper evaluates the influence of the classmates' age on individual academic achievement. The identification strategy explores a mechanism for the division of classes based on age homogeneity, with cutoff value determined by the Brazilian law of age at school entry. Fuzzy regression discontinuity estimates a local average treatment effect of 2.34 standard deviations favorable to students assigned to class with older peers, in comparison to those allocated to classes with younger classmates. The empirical estimations use a unique educational dataset originated from the Brazilian Ministry of Education, which provides a large information set related to the student's scholar environment.
\end{abstract}

Keywords: peer age effects, school achievement, fuzzy regression discontinuity design

\section{Introduction}

Many studies investigate the influence of group composition on student outcomes. On the tracking literature, the concern is to understand if putting together similar individuals turns to be beneficial. The studies on tracking by ability provide mixed evidences, either favorable to this type of sorting (Vardardottir, 2013; Duflo, Dupas \& Kremer, 2008), or not favorable (De Giorgi, Pellizzari \& Woolston, 2010; Lyle, 2009; Schneeweis \& Winter-Ebmer, 2007; Zimmer, 2003). Studies about the impact of gender segregated groups on educational outcomes also offer mixed results (Oosterbeek \& Van Ewijk, 2014; Eisenkopf, Hessami, Fischbacher \& Heinrich, 2011). In the social network literature, Xu and Fan (2018) find that group diversity in terms of immigration and racial status exert differential influences on adolescents' misbehaviors, including skipping school, lying, drinking and smoking.

An interesting group composition is the age homogeneity classrooms, a school policy adopted in several establishments from the public elementary education system in Brazil ${ }^{1}$. Although this type of policy is not defined by law, it is a way around the school principals find to deal with the problem of grade-distortion in this country ${ }^{2}$. Koppensteiner (2018) evaluates this sort of age tracking for the schools of the Brazilian state Minas Gerais, and finds support for the policy, meaning the students allocated to homogenous age groups perform better. Along the international literature, very scarce evidences are available, Ordine, Rose and Sposato (2015) demonstrate that the individual score of students sharing the classroom with pupils "in advance" differs by students' age group and it is higher for youngest pupils. Sandgren and

\footnotetext{
${ }^{1}$ The elementary education system in Brazil comprehends nine years of school, which cover literacy course through $9^{\text {th }}$ grade. It is followed by middle schooling (equivalent to High Scholl in the United States), which covers $10^{\text {th }}$ through $12^{\text {th }}$ grades.

${ }^{2}$ The student is considered in a situation of grade-distortion when the difference between his/ her age and the expected age for the considered grade is greater than or equal to two years. In Brazil, in $2015,30.1 \%$ of the students from $6^{\text {th }}$ to $9^{\text {th }}$ grades in the public education system were considered grade-distorted in average, while only $7.2 \%$ from the private system were in this situation (Instituto Nacional de Estudos e Pesquisas Educacionais Anísio Teixeira [INEP], 2015).
} 
Strøm (2005) find that male students being in classrooms with relatively old peers achieve better in mathematics than other male students.

Motivated by the scarce and still questionable evidences on peer age effects, the goal of this paper is to evaluate the impact of a class division policy based on homogeneity of age on the academic proficiency of $6^{\text {th }}$ grade students from public schools in Brazil. Our empirical strategy resembles that of Koppensteiner (2018), however our identification strategy presents an advantage over his study: the student's school achievement is measured twice in a year. This longitudinal aspect of academic scores permits to control for preexisting differences between students and allows to separate out own relative age effect from the peer age effects. Our empirical estimates are based on fuzzy regression discontinuity models and the exogeneity hypothesis that guides the Principal's decision to form classes is centered on the age variation induced by compulsory school attendance laws. The data comes from a unique educational survey from the Brazilian Ministry of Education (Fundação Joaquim Nabuco [FUNDAJ], 2013).

In addition to this introduction, the paper is organized into six additional sections: section two discusses the econometric method and identification strategy; section three presents a descriptive analysis of the database used; section four discusses the class assignment based on age homogeneity used to divide classrooms; section five applies some validity tests to the discontinuous design studied here; section six assembles the results; and finally, the last section gathers the paper's main conclusions.

\section{Empirical Model and Identification Strategy}

In this study, the empirical strategy explores the fact that some public elementary education schools use a criterion of age homogeneity to divide their $6^{\text {th }}$ grade classes. In Brazil, the school year starts in March and the law establishes that in order to enter the $1^{\text {st }}$ year of elementary education, children must be at least six years old by the end of the school year in December (the younger ones will have to wait until the following year). By the $6^{\text {th }}$ grade, a child will be in the right age if he/ she falls in the range of 132 to 143 months, so the youngest in the class will turn 11 in December (132 months) and the oldest will be 11 years and 11 months by December (or 143 months) ${ }^{3}$. As a result, schools adopting such age criterion present a discontinuity in the probability of a $6^{\text {th }}$ grade student to be allocated to an older class if he/she completes 12 years old by the month of December (or 144 months old). This cutoff date, which separates students into younger and older classes, constitutes, therefore, a quasi-experiment, and this study uses this exogenous discontinuity to estimate the causal effect of peers.

The school performance of students immediately to the left of the 144 months mark provides a valid counterfactual for students to the right of this limit who were allocated to the treatment (or older classes), since the treatment status is random in the vicinity of this limit. It is thus possible to estimate the peer age effects on the individual school performance by simply comparing the school performances of students slightly older or younger than the 144 months, given that, due to the randomization, they should present similar characteristics, except for the treatment status.

The identification of the peer age effects is treated here by using fuzzy regression discontinuity models, where the probability of being assigned to an older class is defined as:

$$
E\left[T_{i, c, s} \mid Z_{i, c, s}\right]=\operatorname{Pr}\left[T_{i, c, s}=1 \mid Z_{i, c, s}=z_{i, c, s}\right]=\delta \cdot 1\left(z_{i, c, s}-\bar{z}\right) \geq 0+g\left(z_{i, c, s}-\bar{z}\right)+u_{i, c, s}
$$

Being $T_{i, c, s}$ the treatment dummy variable, in which $T_{i, c, s}=1$ if the student $i$ in class $c$ and school $s$ is assigned to an older classroom, and $T_{i, c, s}=0$ if the student is assigned to a younger and more age homogeneous classroom. $1(\cdot)$ is the indicator function, taking the value one if the student's $i$ age exceed the threshold age of 144 months in December $\left(\bar{z}=144\right.$ months) and zero otherwise. $Z_{i, c, s}$ is the assignment (also denoted in the literature as "forcing", "running" or "rating") variable used to assign the student $i$ to the treated classrooms. $g(\cdot)$ is a polynomial function on the deviation from the cutoff age and $u_{i, c, S}$ is an unobserved error capturing anything else that might also influence the class assignment decision. The academic achievement of the students allocated to treated and non-treated classes can then be represented by:

$$
Y_{i, c, s}=\alpha+\tau T_{i, c, s}+\sum_{i-1} \beta^{j} X_{i, c, S}^{j}+\sum \zeta^{S} S D_{i, c, s}^{S}+f\left(z_{i, c, s}-\bar{z}\right)+\varepsilon_{i, c, s}
$$

where $Y_{i, c, s}$ is some measure of academic performance in mathematics of student $i$ from class $c$ and school $s, X_{i, c, s}$ is a vector of students characteristics, as well as, their classrooms attributes and $S D_{i, c, s}$ is a vector of school dummies

\footnotetext{
${ }^{3}$ According to legal guidance and standards set by the Brazilian National Board of Education/ Ministry of Education in Resolution CNE/CEB 4/2008, to enter the $1^{\text {st }}$ grade of elementary education, the child must turn six years old along the school year, which ends in December (BRASIL, 2008). In the year of 2010, a new resolution explicitly defined the cutoff date on March, $31^{\text {st }}$ (the beginning of the school year) at the Resolution CNE/CEB 6/2010 (BRASIL, 2010). For the students investigated here, who were in average six years old in 2008, the first Resolution CNE/CEB 4/2008 was applied, whit cutoff date in December.
} 
designated to capture school fixed effects. The coefficient $\tau$ captures the effect of peer age on individual achievement and $\varepsilon_{i, c, s}$ is a random error term. As before, $f(\cdot)$ is a polynomial function on the deviation from the cutoff age.

In the fuzzy design, the conditional probability of participating in the treatment $P(T \mid Z)$ is not a deterministic function of the forcing variable $Z$, thus it needs not to change from zero to one at the threshold age. Such a situation can arise if the incentives to the treatment status change discontinuously at a threshold, without these incentives being powerful enough to move all units from nonparticipation to participation. As such, the probability of the student being treated $T_{i, c, s}$ is instrumented by a dummy variable $D_{i, c, s}$, as denoted by:

$$
D_{i, c, s}=\left\{\begin{array}{l}
0 \text { if } z_{i, c, s}<\bar{z} \\
1 \text { if } z_{i, c, s} \geq \bar{z}
\end{array}\right.
$$

The fuzzy regression discontinuity estimator can be related to the instrumental variable estimator LATE (Local Average Treatment Effect). In this study the LATE estimator is apprehended by the coefficient $\tau$ and, as shown by Hahn, Todd and Van der Klaauw (2001), corresponds numerically to the Wald estimator of instrumental variables in two stages. LATE identifies the average treatment effect only for those individuals who changed their treatment status when the assignment variable $Z$ passed the cutoff value $\bar{z}$, that is, only for the compliers. In the case studied here, the compliers are the students who, in December, were 144 months or older and were allocated for older classes, or for younger classes, if their age was lower than this limit.

The treatment effect will be tested on both the student's grades at the beginning and the end of the school year and on their variation. However, since in the sample being used over $66 \%$ of the students are newcomers, the expectation is that the influence of interacting with peers of different ages shows up more strongly on the improvement of their performance over the school year. Indeed, as will be discussed forward, the LATE effect on the initial grades was not significant, which may be credited to two reasons: (i) the division of classes was not based on the student's academic performance a priori, and (ii) there was not enough time for the peer effects to spread over the class.

All equations are estimated using triangular kernel functions to construct the local polynomial regression-discontinuity estimators. The optimal bandwidth is chosen by Calonico, Cattaneo and Titiunik (2014) procedure. Robust standard errors are calculated as described by Calonico, Cattaneo, Farrell and Titiunik (2017). Estimates robustness are checked by implementing a variety of functional forms, including second order polynomials, interaction between the assignment variable and the treatment and also additional covariates.

\section{The Dataset and Descriptive Statistics of the Variables}

This article uses a unique dataset from a survey conducted by Fundação Joaquim Nabuco in 2013 (FUNDAJ, 2013) with a sample of students in the $6^{\text {th }}$ grade of public schools in the city of Recife, Pernambuco State of Brazil. The research evaluated student performance on two math tests (which were given in at the beginning and the end of the school year, in the months of March and November, respectively). Interviewers also collected a large set of information on internal and external aspects of school life through four types of questionnaires (one for students, one for the primary adult responsible for each child's academic life, one for the math teacher, and another one for the school principal). In total, 4,191 students, 3,670 parents or guardians, 120 principals, and 131 teachers from 120 schools were interviewed. The school units were spatially distributed among 18 micro-regions of Recife ${ }^{4}$. In some schools with higher enrollment rate in the $6^{\text {th }}$ year, two groups were randomly selected, not just one. For this reason, the total number of classrooms selected for the sample was 146 .

The sample used in this paper's estimates is restricted to schools with two classes under research and whose principals'

\footnotetext{
${ }^{4}$ Each political-administrative region of Recife is divided into three micro-regions "in order to define municipal interventions at the local level and in coordination with the population". Each region is composed of one or more of the 94 Districts established by Brazilian Law. The 18 micro regions correspond to the division of Political-Administrative Regions, which was conceived in 1995 by the Department of Social Policies to organize Participatory Budgeting meetings which had been limited to associations and their representatives (Prefeitura do Recife, 2005).
} 
revealed they divide classes according to the age homogeneity criterion ${ }^{5}$. Among the 120 schools researched by FUNDAJ (2013), 85 use the age homogeneity factor to form $6^{\text {th }}$ grade classes, 6 schools adopt the opposite criterion (age heterogeneity), 6 divide classes by the heterogeneity of school performance, 2 by the homogeneity of school performance, and 21 schools do not use any criterion. Among the 85 schools that adopt the age policy to form classes, only 13 of them have two classes with average ages statistically different among themselves; that is to say, in those institutions, it is possible to identify two distinct types of classes: one with older students and higher dispersal in age distribution, and another, more homogeneous, with younger students. Taking into considering only the students who took both math exams in those 13 schools, the final sample available is of 586 students. Table 1 presents the definition and descriptive statistics of the variables selected for the estimated models of this paper for each type of classroom.

Table 1. Definition and descriptive statistics of the variables

\begin{tabular}{|c|c|c|c|c|c|}
\hline & & Younger cl & lass & Older cla & \\
\hline & Definition of Variables & Mean & Std. Dev. & Mean & $\begin{array}{l}\text { Std. } \\
\text { Dev. }\end{array}$ \\
\hline $\begin{array}{l}\text { Math score at the } \\
\text { beginning of the } \\
\text { year }\end{array}$ & $\begin{array}{l}\text { Grade of student } i \text { on math test conducted by FUNDAJ (2013) at the beginning of } \\
\text { school year. Rating scale ranges from } 0 \text { to } 100 \text {. }\end{array}$ & 40.768 & 14.587 & 36.696 & 13.831 \\
\hline $\begin{array}{l}\text { Math score at the } \\
\text { end of the year }\end{array}$ & $\begin{array}{l}\text { Grade of the student } i \text { on math test conducted by FUNDAJ (2013) at the end of school } \\
\text { year. Rating scale ranges from } 0 \text { to } 100 \text {. }\end{array}$ & 40.196 & 15.072 & 35.357 & 14.087 \\
\hline $\begin{array}{l}\text { Growth rate of the } \\
\text { math scores }\end{array}$ & Calculated as: (Initial score - Final score)/ Initial score & 0.088 & 0.539 & 0.117 & 0.774 \\
\hline $\begin{array}{l}\text { Age in December } \\
\text { (months) }\end{array}$ & Age of the student in the month of December (months) & 145.667 & 8.768 & 156.982 & 12.537 \\
\hline $\begin{array}{l}\text { Dummy for male } \\
\text { students }\end{array}$ & Dummy equals 1 if student is male & 0.484 & 0.501 & 0.646 & 0.479 \\
\hline $\begin{array}{l}\text { Dummy for white } \\
\text { students }\end{array}$ & $\begin{array}{l}\text { Dummy equals } 1 \text { if students declare themselves as white and } 0 \text { if they describe } \\
\text { themselves as black, mixed race, Asian, or indigenous }\end{array}$ & 0.203 & 0.403 & 0.212 & 0.410 \\
\hline $\begin{array}{l}\text { Dummy for new } \\
\text { students }\end{array}$ & $\begin{array}{l}\text { Dummy equals } 1 \text { if student has been attending the school researched for less than one } \\
\text { year }\end{array}$ & 0.696 & 0.461 & 0.625 & 0.485 \\
\hline $\begin{array}{l}\text { Dummy for failed } \\
\text { students }\end{array}$ & Dummy equals 1 if student has failed one year or more & 0.207 & 0.406 & 0.534 & 0.500 \\
\hline $\begin{array}{l}\text { Student's } \\
\text { perception about } \\
\text { own personality }\end{array}$ & $\begin{array}{l}\text { Student answers the question "I would change something in my personality": } 1= \\
\text { strongly agree, } 2 \text { = perhaps, } 3=\text { strongly disagree }\end{array}$ & 2.443 & 0.872 & 2.541 & 0.816 \\
\hline $\begin{array}{l}\text { Guardian's } \\
\text { education level }\end{array}$ & $\begin{array}{l}\text { Parents/guardians answer the question: "What is the highest grade finished } \\
\text { successfully?": } 1=1 \text { year (literacy), } \ldots, 9=9 \text { years; } 10=1 \text { year of high school, } \ldots, 12 \\
=\text { last year of high school; } 13=1 \text { year of university } \ldots, 18=\text { final year of university }\end{array}$ & 8.097 & 3.377 & 7.863 & 3.422 \\
\hline $\begin{array}{l}\text { Dummy for } \\
\text { married guardians }\end{array}$ & $\begin{array}{l}\text { Dummy equals } 1 \text { for parents/guardians married with a legally recognized union or } \\
\text { common-law marriage }\end{array}$ & 0.328 & 0.471 & 0.252 & 0.435 \\
\hline $\begin{array}{l}\text { Dummy for white } \\
\text { guardians }\end{array}$ & $\begin{array}{l}\text { Dummy equals one for parents/guardians who declare themselves white and } 0 \text { if they } \\
\text { declare themselves as black, mixed race, Asian, or indigenous }\end{array}$ & 0.196 & 0.397 & 0.161 & 0.368 \\
\hline $\begin{array}{l}\text { Household's } \\
\text { monthly income }\end{array}$ & Household's monthly income in Brazilian Reais (R\$) - current value of May, 2003 & 875.782 & 557.372 & 863.851 & 530.091 \\
\hline $\begin{array}{ll}\text { Dummy } & \text { for } \\
\text { guardians } & \\
\text { beneficiary } & \text { of } \\
\text { social program } & \end{array}$ & Dummy equals 1 if parents/guardian receives any government financial assistance & 0.636 & 0.482 & 0.658 & 0.475 \\
\hline $\begin{array}{l}\mathrm{N}^{\mathrm{o}} \text { of students in } \\
\text { class }\end{array}$ & $\mathrm{N}^{\circ}$ of enrolled students in the classroom & 33.771 & 9.050 & 35.700 & 5.577 \\
\hline $\begin{array}{l}\text { Dummy for male } \\
\text { teachers }\end{array}$ & Dummy equals 1 if teacher is male & 0.350 & 0.478 & 0.489 & 0.501 \\
\hline $\begin{array}{l}\text { Dummy for white } \\
\text { teachers }\end{array}$ & $\begin{array}{l}\text { Dummy equals } 1 \text { if teachers declare themselves as white and } 0 \text { if they describe } \\
\text { themselves as black, mixed race, Asian, or indigenous }\end{array}$ & 0.268 & 0.444 & 0.346 & 0.477 \\
\hline Teacher's age & $\begin{array}{l}\text { Teachers answer the question: "What is your age?": } 1=\text { less than } 25 \text { years old; } 2=25 \\
\text { to } 29 \text { years old; } 3=30 \text { to } 39 \text { years old; } 4=40 \text { to } 45 \text { years old; } 5=50 \text { to } 54 \text { years old; } 6 \\
=55 \text { years old or more }\end{array}$ & 3.817 & 1.252 & 3.668 & 1.104 \\
\hline $\begin{array}{l}\text { Teacher's } \\
\text { experience }\end{array}$ & $\begin{array}{l}\text { Teachers answer the question: "How long have you been teaching } 6^{\text {th }} \text { grade classes?": } \\
1=2 \text { years or less; } 2=\text { more than } 2 \text { to } 4 \text { years; } 3=\text { more than } 4 \text { to } 6 \text { years; } 4=\text { more } \\
\text { than } 6 \text { to } 8 \text { years; } 5=\text { more than } 8 \text { years }\end{array}$ & 3.092 & 1.466 & 3.550 & 1.340 \\
\hline $\begin{array}{l}\text { Dummy for } \\
\text { teachers graduated } \\
\text { in mathematics }\end{array}$ & $\begin{array}{l}\text { Dummy equals } 1 \text { if they graduated in mathematics and } 0 \text { if they graduated in other } \\
\text { disciplines }\end{array}$ & 0.310 & 0.463 & 0.354 & 0.479 \\
\hline \multicolumn{2}{|l|}{ No. of observations } & \multicolumn{2}{|l|}{306} & \multicolumn{2}{|l|}{280} \\
\hline
\end{tabular}

${ }^{5}$ The interviewed principal replies to the following question:

WHAT IS THE CRITERION USED IN FORMING 6 $^{\text {TH }}$ GRADE CLASSES IN THIS SCHOOL? (Check only ONE alternative.)

[1] Homogeneity regarding age (students with the same age).

[2] Homogeneity regarding school performance (students with similar performances).

[3] Heterogeneity regarding age (students with different ages).

[4] Heterogeneity regarding school performance (students with different performances).

[5] There was no criterion.

[9] Not known / not answered. 
Source: Original compilation based on FUNDAJ (2013).

${ }^{+}$The initial average score was slightly higher than the final, for both types of classes, but the final grade presented a higher dispersion, which explains why the average grade growth rate remains positive between both exams.

\section{Class Assignment}

In Brazil, it is a common practice amongst public elementary schools to adopt the age homogeneity criterion to form classes. For the year of 2013, 34\% of public schools formed their classes using such criterion (INEP, 2013). The Brazilian law for the age at school entry, in force until 2009, defined December as the limit month to establish if the student is in the right age-grade. Thus, a child in the 6th grade would be in the right age if he/ she falls in the range of 132 to 143 months, so the youngest in the class will turn 11 in December (132 months) and the oldest will be 11 years and 11 months by December (or 143 months).

For the sample used here, which comprehends schools that adopt the age homogeneity criterion to form classes and 6th grade students, the pupils who turn 12 years old by the month of December tend to be allocated to classes with older students, while those who remain 11 the whole year, tend to be allocated with younger ones. As a result, around the age of 144 months in December, it is observed a discontinuity in the conditional probability of being allocated to the older class, showing that students 144 months old or older tend to be systematically allocated to treatment classes $\mathrm{T}=1$, and to control classes $\mathrm{T}=0$ otherwise, as illustrated in Figure 1.

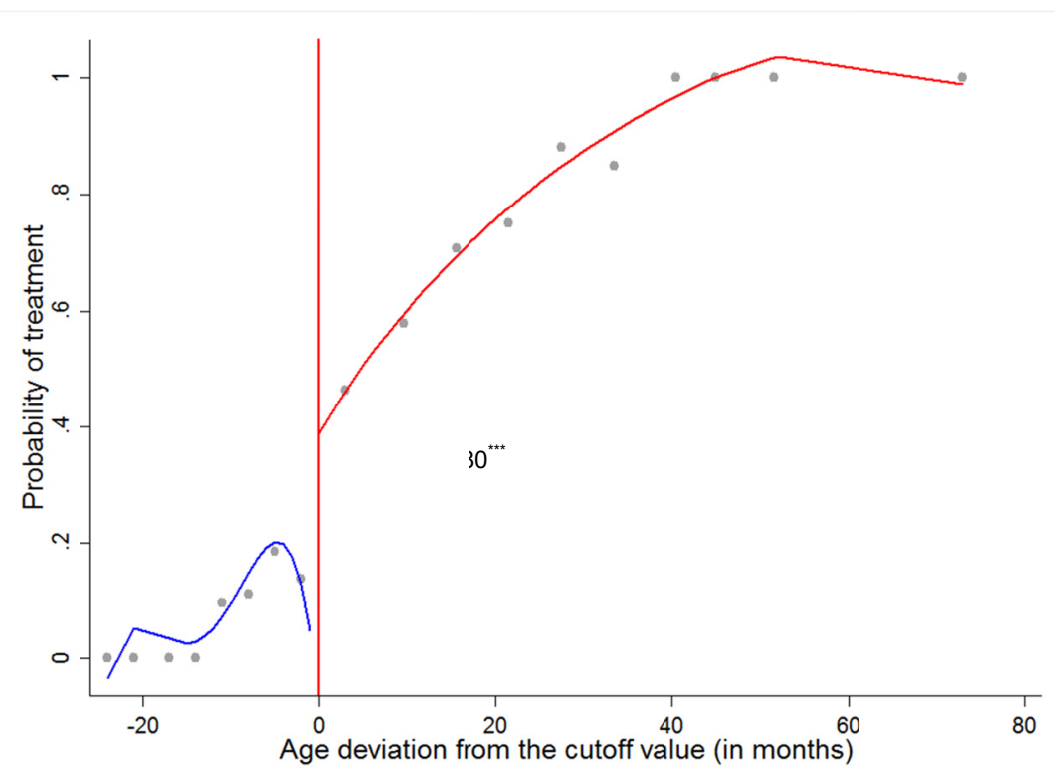

Figure 1. Conditional probability of being assigned to older classrooms

Source: original compilation based on FUNDAJ (2013).

This graph represents the first-stage RD estimate using triangular kernel functions, according to the model: $\operatorname{Pr}\left[\mathrm{T}_{\mathrm{i}, \mathrm{c}, \mathrm{s}}=1\right.$ | $\mathrm{Z}_{\mathrm{i}, \mathrm{s}, \mathrm{s}}=\mathrm{Z}_{\mathrm{i}, \mathrm{c}, \mathrm{s}}=\delta \cdot 1\left(\mathrm{z}_{\mathrm{i}, \mathrm{s}, \mathrm{s}} \mathrm{z}^{-}\right) \geqslant 0+\mathrm{g}\left(\mathrm{z}_{\mathrm{i}, \mathrm{cs}, \mathrm{s}} \mathrm{Z}^{-}\right)+\mathrm{u}_{\mathrm{i}, \mathrm{css}}$. The dependent variable is the treatment assignment $\mathrm{T}$ taking the value one if the student is assigned to older classes and the value zero otherwise. The assignment variable is the student age in months centered on the threshold value $\bar{z} \overline{:} z_{i, c, s}-144$. Thus, the value of the student age at the cutoff point becomes zero. The optimal bandwidth is chosen by Calonico et al. (2014) procedure. Robust standard errors are calculated as described by Calonico et al. (2017). ***, **, * represent the statistical significance at the $1 \%, 5 \%$ and $10 \%$ levels, respectively.

This sort of class assignment rule generates two distinct types of classes according to the students' age distributions, as can be seen from Figure 2. The average age, in the reference month of December, for the older classes is 157 months (standard deviation of 12.54) and 146 months for younger classes (standard deviation of 8.77), while the maximum and minimum ages are 217 and 133 months, and 175 and 120 months, respectively. 


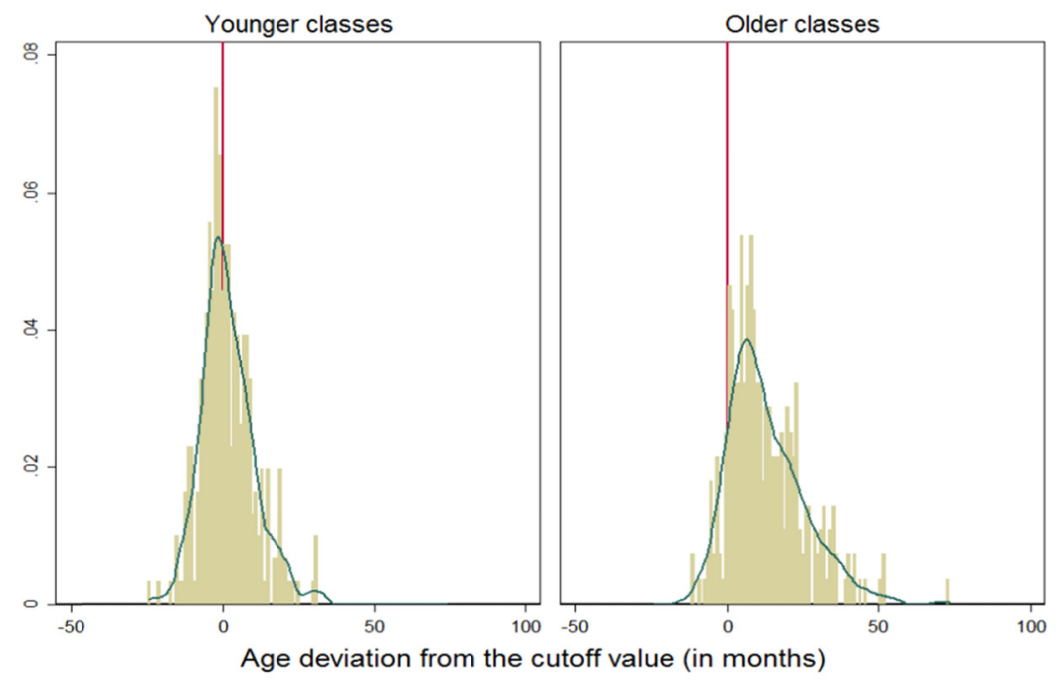

Figure 2. Distribution of students' age by class type.

Source: original compilation based on FUNDAJ (2013).

The centre of each graph is zero, which represents students who are 144 months old (or 12 years old) in December.

An essential point to be discussed in such class assignment policy refers to the exogeneity of the cutoff age value, that is, to know if the rule set by the Brazilian Ministry of Education is actually enforced by the Principals and it is not manipulated by them. In interviews, the Principals of 13 schools reported that the only criterion adopted for dividing their 6th grade classes was that of age, as prescribed by law.

In order to identify if the age of 12 years old (or 144 months in December) may, in fact, be considered the cutoff age for all schools studied, we perform a set of tests to check for jumps at points where there should be no jumps. We estimate RD models for different cutoff values in the students' age interval comprehending 11 years until 12 years and 2 months old in December. The results are presented in Table 2 and represent first-stage RD estimates, according to Equation (1). As can be seen in column (1), there is an increase of about 38 percentage points (p.p) in the probability of being allocated to older classrooms at the age of 12 years old in December, while in the mark of 11 years and 10 months (or 142 months) there is a significant reduction, about 24 p.p, in the probability of being assigned for the treatment classes. This last discontinuity can be attributed to the fact that age value of 142 months represents the mode in the younger classes, while in the treatment and older classes there are only two students with this specific age in December, inducing the jump representing the smaller chance to be assigned to older classes, as illustrated in the Figure 3. Such a situation could be an indication that Principals are picking other cutoff point then the 144 months expected by law, which would violate the RD design. However, it doesn't seem reasonable provided the probability of treatment assignment in the mark of 142 months is reduced instead of increased and it does not make sense to have a smaller mass of older students in the treatment classes than in the younger ones.

Table 2. Differences in the probability of receiving the treatment for various age cutoff values

\begin{tabular}{llll}
\hline Age in December & $\mathbf{N}^{\mathbf{0}}$ obs. within bandwidth & $\boldsymbol{\delta}$ & Standard errors \\
\hline 11 years & - & - & - \\
11 years and 1 month & 305 & 0.069 & 0.062 \\
11 years and 2 months & 40 & -0.362 & 0.283 \\
11 years and 3 months & 70 & 0.197 & 0.233 \\
11 years and 4 months & 109 & -2.930 & 0.370 \\
11 years and 5 months & 133 & 0.107 & 0.146 \\
11 years and 6 months & 119 & 0.134 & 0.147 \\
11 years and 7 months & 161 & 0.066 & 0.159 \\
11 years and 8 months & 183 & -0.217 & 0.167 \\
11 years and 9 months & 227 & -0.025 & 0.114 \\
$\mathbf{1 1}$ years and 10 months & $\mathbf{2 2 0}$ & $\mathbf{- 0 . 2 4 3}$ & $\mathbf{0 . 1 3 7}$ \\
11 years and 11 months & 269 & 0.059 & 0.106 \\
$\mathbf{1 2}$ years & $\mathbf{2 4 6}$ & $\mathbf{0 . 3 8 0}$ & $\mathbf{0 . 1 0 4}$ \\
12 years and 1 month & 245 & 0.161 & 0.139 \\
12 years and 2 months & 206 & -0.169 & 0.168 \\
\hline
\end{tabular}

Source: original compilation based on FUNDAJ (2013). 
This table represents the first-stage RD estimates using triangular kernel functions and considering different cutoffs $\bar{z}$, according to the model: $\operatorname{Pr}\left[T_{i, c, s}=1 \mid Z_{i, c, s}=z_{i, c, s}\right]=\delta \cdot 1\left(z_{i, c, s}-\bar{z}\right) \geq 0+g\left(z_{i, c, s}-\bar{z}\right)+u_{i, c, s}$. The dependent variable is the treatment assignment $T$ taking the value one if the student is assigned to older classes and the value zero otherwise. The assignment variable is the student age in months centered on the threshold value $\bar{z}: z_{i, c, s}-\bar{z}$. Thus, the value of the student age at the cutoff point becomes zero. The optimal bandwidth is chosen by Calonico et al. (2014) procedure. Robust standard errors are calculated as described by Calonico et al. (2017). ${ }^{* * *},{ }^{* *},{ }^{*}$ represent the statistical significance at the $1 \%, 5 \%$ and $10 \%$ levels, respectively.

${ }^{+}$At the age of 11 years or 132, there weren’t enough observations to perform calculations.

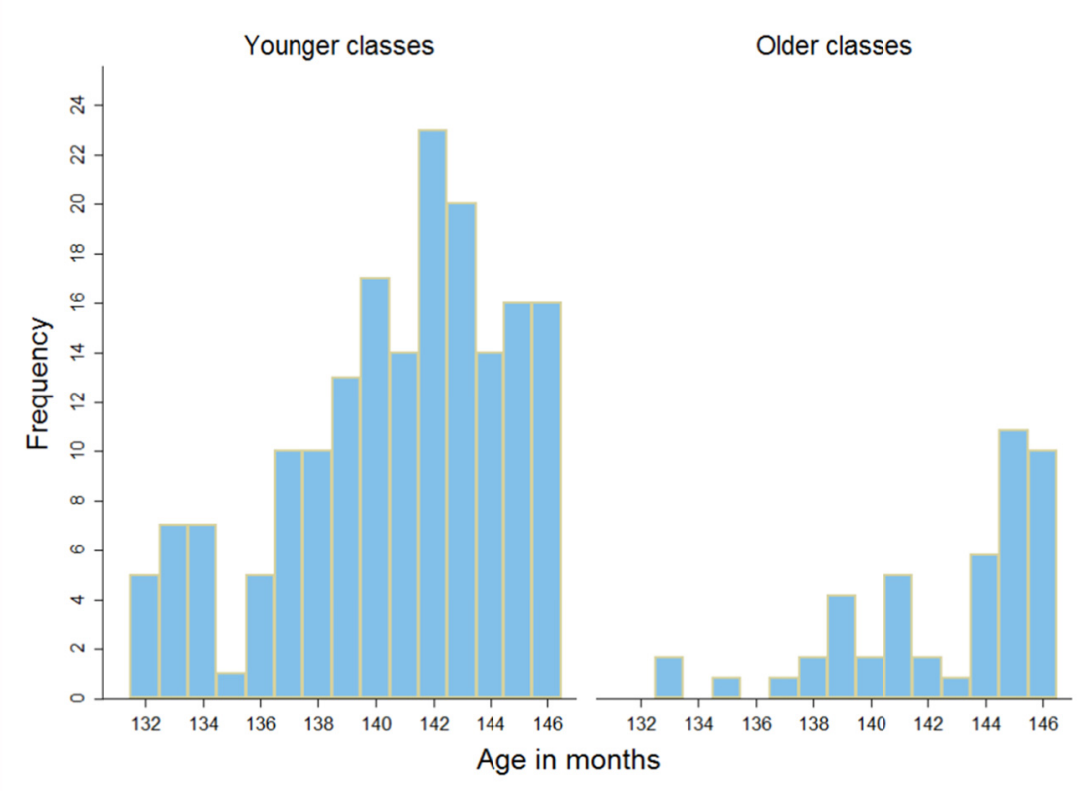

Figure 3. Distribution of student's age within the range of 132 to 146 months, by class type

Source: original compilation based on FUNDAJ (2013).

\section{Validity Tests for the Discontinuous Design}

The internal validity of the regression discontinuity approach is based on the fundamental assumption that the students or their parents do not manipulate the assignment age $\mathrm{Z}$ around the threshold value. This implies that the conditional regression functions of outcomes, under treatment or control status, to be continuous around the cutoff value $\bar{z}$ : $\mathrm{E}\left[\mathrm{Y}_{\mathrm{i}, \mathrm{c}, \mathrm{s}}(1) / \mathrm{Z}_{\mathrm{i}, \mathrm{c}, \mathrm{s}}=\overline{\mathrm{z}}\right]$ and $\mathrm{E}\left[\mathrm{Y}_{\mathrm{i}, \mathrm{c}, \mathrm{s}}(0) / \mathrm{Z}_{\mathrm{i}, \mathrm{c}, \mathrm{s}}=\overline{\mathrm{z}}\right]$ are continuous. One way to check this condition is to observe if the density of the student's age is continuous around the cutoff point, for any "jump" in the density of this variable may indicate that students self-select themselves for treatment.

A self-selection hypothesis could be based on parent's belief that being among the youngest in the class would lower their children academic achievement, and then they would have incentives to plan their children birth to occur after December, driving them to be allocated to the treated class when they reach the 6th year. In order to check for discontinuities in the running variable $Z$, we implement the McCrary (2008) procedure: a Wald test in which the density is continuous under the null hypothesis. In the first McCrary test, illustrated in Figure 4, the students present higher probability to be born on January than in December. Nevertheless, it is helpful to consider how reasonable is the birth planning hypothesis in the context of the population studied here? Most of the students from the elementary public education system in Brazil come from less educated and poorer families, as compared to those students from the private schools, whose families could be expected to plan their children birthday. Indeed, if the birthday manipulation hypothesis is valid for more educated and wealthier parents, then the discontinuity should show more sharply in the subsample of parents with such profile. The second and third graphs of Figure 4, however, confirm there is not a statistically significant difference between births in the months of December and January for this group. Additionally, Matta, Ribas, Sampaio and Sampaio (2016) also demonstrate that for the whole Pernambuco state population there is no evidence of a jump in the probability of being born before or after January 1st, for the children births between July 1984 and July 1988. 

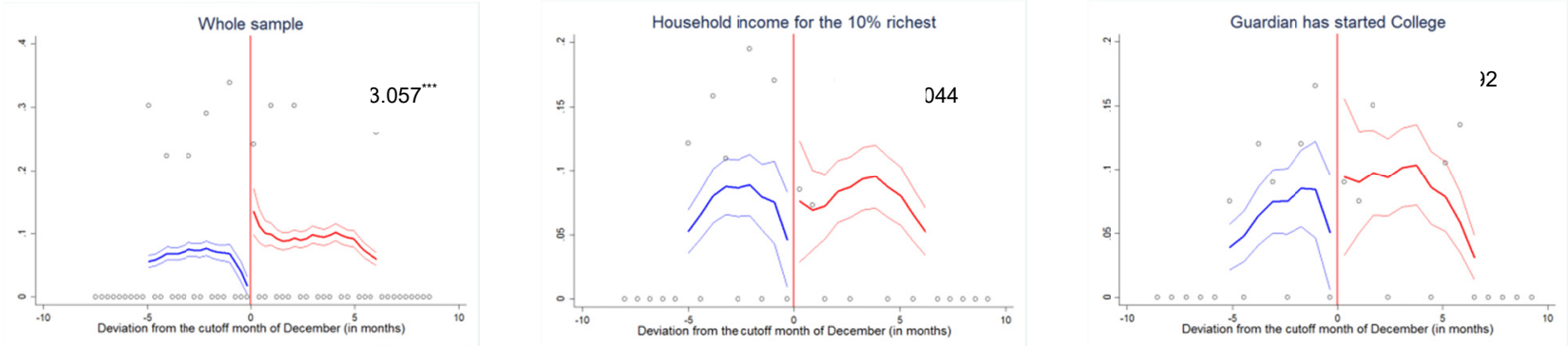

Figure 4. McCrary density tests for the students' months of birth

Source: original compilation based on FUNDAJ (2013).

The centre of each graph is zero, which represents students who are 144 months old (or 12 years old) in December. $\theta$ is the McCrary's estimator (2008) for log density discontinuity, with standard errors in parentheses.

*** represents statistical significance at the $1 \%$ level.

Another condition necessary to hold in our RD design is the assumption that the pupil's age is the single factor used by the school Principals to structure their 6th grade classes, for any other factor being used, would confound the identification of the peer age effects.

An indirect way to check such assumption is to verify if the individuals, before and after the cutoff age, display similar observable characteristics. If this kind of balancing for relevant characteristics is verified, then there is an additional evidence of the validity of the discontinuous design. The expectation, a priori, is for both groups to be similar in their observable characteristics (and non-observable as well, if the randomization has been well-established).

Table 3 presents average values around the cutoff for the individual and family attributes of students within the range of 132 to 146 months old, in December, by type of class. We observe that students of both, younger and older classes, in fact, present similar individual characteristics and family backgrounds, since no statistically significant differences in the averages between them can be noticed. The only exceptions are the initial grade and the proportion of newcomers, once the average math scores at the beginning of the year for the younger classrooms are higher than the ones observed in the older group and also the proportion of new students in the school. These differences may denote that the Principal has used additional criteria to form the classes, other than the student's age. Further, we test this supposition by running $\mathrm{RD}$ models with other covariates acting as pseudo outcomes, in order to verify if the treatment also affects other covariates. As will be seen, we indeed confirm there are no significant discontinuities in the tested covariates.

Table 3. Balancing of the students' characteristics within the age interval of 132 to 146 months, by class type

\begin{tabular}{llll}
\hline Students' characteristics & Younger classes & Older classes & Difference \\
\hline Grade at the beginning of the year & 42.23 & 37.00 & $5.33^{* \pi}$ \\
& $(1.57)$ & $(1.83)$ & $(2.63)$ \\
Grade at the end of the year & 40.45 & 38.50 & $(2.57)$ \\
& $(1.41)$ & $(2.18)$ & -0.05 \\
Dummy for male students & 0.49 & 0.54 & $(0.09)$ \\
& $(0.05)$ & $(0.07)$ & -0.04 \\
Dummy for white students & 0.19 & 0.23 & $(0.07)$ \\
& $(0.04)$ & $(0.06)$ & $0.17^{* *}$ \\
Dummy for new students & 0.76 & 0.59 & $(0.08)$ \\
& $(0.04)$ & $(0.07)$ & -0.06 \\
Dummy for failed students & 0.12 & 0.18 & $(0.06)$ \\
Student's perception about own personality & $(0.03)$ & $(0.05)$ & -0.01 \\
& $(0.08)$ & 2.44 & $(0.15)$ \\
Guardian's education level & 8.24 & $(0.12)$ & -0.55 \\
& $(0.37)$ & 8.79 & $(0.61)$ \\
Dummy for married guardians & 0.24 & $(0.38)$ & -0.01 \\
& $(0.04)$ & 0.26 & $(0.08)$ \\
Dummy for white guardians & 0.18 & $0.07)$ & 0.04 \\
Household's monthly income & $(0.04)$ & $(0.05)$ & $(0.07)$ \\
Dummy for guardians beneficiary of social & $(63.62$ & 801.21 & 57.31 \\
program & $(0.05)$ & $(54.28)$ & $(102.09)$
\end{tabular}

Source: original compilation based on FUNDAJ (2013).

${ }^{* * *},{ }^{* *},{ }^{*}$ represent the statistical significance at the $1 \%, 5 \%$ and $10 \%$ levels, respectively. 
Differences in the standards of classes and teachers, relative to treatment and control groups, are also illustrated in Table 4. We notice that teachers' age and level of education are, on average, similar between both classes; however, in the older classes there is a higher preponderance of male teachers, as well as teachers with more experience with 6th grade classes. This could be a signal that the school Principals may be benefitting more "experienced" teachers by allocating them to younger classes who are, a priori, less problematic.

Table 4. Balancing of teachers and class characteristics for the students within the age interval of 132 to 146 months, by class type

\begin{tabular}{lccc}
\hline Characteristics & Younger classes & Older classes & Difference \\
\hline No of students in class & & & -1.66 \\
& 33.24 & 34.90 & $(1.42)$ \\
Dummy for male teachers & $(0.92)$ & $(0.59)$ & -0.02 \\
& 0.35 & 0.38 & $(0.08)$ \\
Dummy for white teachers & $(0.05)$ & $(0.07)$ & -0.08 \\
Teacher's age & 0.24 & 0.32 & $(0.07)$ \\
& $(0.04)$ & $(0.07)$ & -0.13 \\
Teacher's experience & 3.85 & 3.98 & $(0.20)$ \\
Dummy for teachers & $(0.12)$ & $(0.14)$ & $-\mathbf{0 . 8 1}$ \\
mathematics & 2.97 & 3.78 & $(0.23)$ \\
\hline
\end{tabular}

Source: original compilation based on FUNDAJ (2013).

Age range intervals: (3) 30 to 39 years old, (4) 40 to 49 years old. Teacher's experience intervals: (2) more than 2 to 4 years; (3) more than 4 to 6 years; (4) more than 6 to 8 years. ${ }^{* * *},{ }^{* *},{ }^{*}$ represent the statistical significance at the $1 \%, 5 \%$ and $10 \%$ levels, respectively.

The imbalance of relevant characteristics are also tested by estimating discontinuous regression models for the students and teachers attributes presented in Table 3 and Table 4. Specifically the concern is to check if the student's performance and the teacher's gender and experience are also guiding the classes formation, as evidenced by the descriptive just presented. The RD estimates are depicted in Table 5 and there is no evidence of discontinuities in other covariates concerning students or teachers characteristics, reinforcing the balancing property between the two types of classes in the neighborhood of the cutoff age.

Table 5. Estimations of discontinuous regressions on the characteristics of students and teachers

\begin{tabular}{|c|c|c|c|}
\hline Characteristics of students and teachers & $\begin{array}{l}\mathrm{N}^{\mathrm{o}} \text { obs. within } \\
\text { bandwidth }\end{array}$ & $\tau$ & Standard errors \\
\hline Grade at the beginning of the year & 275 & -0.890 & 0.781 \\
\hline Grade at the end of the year & 201 & 1.523 & 1.004 \\
\hline Dummy for male students & 275 & -0.146 & 0.387 \\
\hline Dummy for white students & 239 & 0.157 & 0.364 \\
\hline Dummy for new students & 158 & 0.372 & 0.503 \\
\hline Dummy for failed students & 273 & 0.221 & 0.215 \\
\hline Student's perception about own personality & 244 & -1.118 & 0.581 \\
\hline Guardian's education level & 214 & -1.222 & 2.655 \\
\hline Dummy for married guardians & 177 & 0.341 & 0.388 \\
\hline Dummy for white guardians & 274 & -0.327 & 0.321 \\
\hline Household's monthly income & 216 & 163.67 & 242.91 \\
\hline $\begin{array}{l}\text { Dummy for guardians beneficiary of social } \\
\text { program }\end{array}$ & 176 & -0.331 & 0.432 \\
\hline $\mathrm{N}^{\mathrm{o}}$ of students in class & 311 & -3.476 & 7.250 \\
\hline Dummy for male teachers & 246 & -0.310 & 0.404 \\
\hline Dummy for white teachers & 246 & 0.275 & 0.336 \\
\hline Teacher's age & 275 & 0.485 & 0.870 \\
\hline Teacher's experience & 246 & 1.071 & 1.113 \\
\hline Dummy for teachers graduated in mathematics & 246 & -0.1207 & 0.3697 \\
\hline
\end{tabular}

Source: original compilation based on FUNDAJ (2013).

Each row of this table represents the RD estimates of students and teachers characteristics using triangular kernel functions, according to the model $Y_{i, c, s}=\alpha+\tau T_{i, c, s}+\gamma\left(z_{i, c, s}-\bar{z}\right)+\varepsilon_{i, c, s}$. The dependent variable of each regression is described in the first column. The assignment variable is the student age in months centered on the threshold value $\bar{Z}$ : $z_{i, c, s}-144$. Thus, the value of the student age at the cutoff point becomes zero. The optimal bandwidth is chosen by Calonico et al. (2014) procedure. Robust standard errors are calculated as described by Calonico et al. (2017). 
It is interesting to note that even for the students' initial and final grades, the RD estimates do not reveal differences in the averages of both classes, in the neighborhood of the cutoff age. Based on such evidence, the analysis of the effect of a class division policy based on homogeneity of age will focus on the improvement of the student's performance over the school year, measured here by the growth rate of the math scores. Results are next presented in the following Section.

\section{Results}

In this section, we present the main results about the effects of a class division policy based on student's age on individual academic proficiency. As already mentioned, the analysis focuses on the improvement of the student's mathematical performance over the year due to this variable's higher capacity of capturing what is actually intended to be measured, that is: how much of the individual's cumulative learning can be attributed to the peer age effects. Table 6 gathers the estimations for a variety of model specifications and three distinct sub-samples: the whole sample of schools, the subsample of schools in which the same instructor teaches both class types and the subsample of schools in which different teachers instruct different class types.

Considering the whole sample and the specification of Model 1, we observe that the effect of being assigned to treated and older class increases by 2.34 standard deviations (sds) the student's growth rate of math scores throughout the year (see Column 1, Table 6). For the optimal bandwidth, the estimates remain stable across different specification models, reinforcing the validity of the $\mathrm{RD}$ design, as well as the evidence that the student's age is the single factor used by the school Principals to divide class and the threshold age has not been manipulated by them. When the bandwidth diverges from the optimal size defined by the Calonico et al. (2014) procedure, results become less robust. For half and twice the optimal bandwidth, only the simplest specification (Model 1) remains significant (see Columns 2 and 3, Table 6). Increasing the complexity of the models reduces the power of analysis, a limiting factor especially in smaller data sets, such as the case studied here with a reduced number of observations.

In Columns 7 to 9 , we estimate models for two separated samples due to evidence previously presented in Table 4 of a certain preponderance of more experienced teachers instructing treated classes. The purpose of this exercise is to control for the teacher's heterogeneity within the same school, at least in their observable characteristics, since it is possible for the same teacher to change their behavior and teaching manner for different classes. For the schools, in which the same instructor teaches both types of classes (see Columns 4 to 6, Table 6), all the model specifications, except Model 2, present significant peers age effect and the coefficient estimates are similar in magnitude to the results found for the whole sample. Again, the results are less robust to different bandwidths.

Finally, for the subsample of schools in which different instructors teach different classes, no significant effect was found, as illustrated in Columns 7 to 9 of Table 6. This important result shows that the differences in the students' performances around the cutoff age are not due to teacher heterogeneity. However, when any heterogeneity exists, as in the case of the whole school sample, it is not sufficient to eliminate the presence of the peer age effects.

Table 6. The effect of peer age on student's educational achievement

\begin{tabular}{|c|c|c|c|c|c|c|c|c|c|}
\hline \multirow[b]{2}{*}{ Model specifications } & \multicolumn{3}{|c|}{ All $(\tau)$} & \multicolumn{3}{|c|}{ Same teacher $(\tau)$} & \multicolumn{3}{|c|}{ Different teachers $(\tau)$} \\
\hline & $\begin{array}{c}\text { Optimal } \\
\text { h } \\
(1)\end{array}$ & $\begin{array}{l}\text { Half h } \\
(2)\end{array}$ & $\begin{array}{c}\text { Twice } \\
\mathrm{h} \\
(3)\end{array}$ & $\begin{array}{c}\text { Optimal } \\
\text { h } \\
\text { (4) }\end{array}$ & $\begin{array}{c}\text { Half h } \\
(5)\end{array}$ & $\begin{array}{c}\text { Twice } \\
\mathrm{h} \\
(6)\end{array}$ & $\begin{array}{c}\text { Optimal } \\
\text { h } \\
\text { (7) }\end{array}$ & $\begin{array}{c}\text { Half } \mathrm{h} \\
(8)\end{array}$ & $\begin{array}{c}\text { Twice } \\
\mathrm{h} \\
\text { (9) }\end{array}$ \\
\hline $\begin{array}{l}\text { Model 1: Simple linear } \\
Y_{i, c, s}=\alpha+\tau T_{i, c, s}+\gamma\left(z_{i, c, s}-\bar{z}\right)+\varepsilon_{i, c,}\end{array}$ & $\begin{array}{l}2.236^{* *} \\
(1.046)\end{array}$ & $\begin{array}{l}2.186^{*} \\
(1.175)\end{array}$ & $\begin{array}{l}1.170^{* *} \\
(0.782)\end{array}$ & $\begin{array}{c}2.244^{*} \\
(1.236)\end{array}$ & $\begin{array}{l}2.118^{*} \\
(1.125)\end{array}$ & $\begin{array}{l}1.333^{*} \\
(0.773)\end{array}$ & $\begin{array}{c}2.791 \\
(2.051)\end{array}$ & $\begin{array}{c}1.747 \\
(3.084)\end{array}$ & $\begin{array}{c}1.700 \\
(1.520)\end{array}$ \\
\hline $\begin{array}{l}\text { Model 2: Linear interaction } \\
Y_{i, c, s}=\alpha+\tau T_{i, c, s}+\gamma\left(z_{i, c, s}-\bar{z}\right)+\delta\left(z_{i, c, s}-\bar{z}\right) \cdot T_{i, c, s}+\varepsilon_{i, c, s}\end{array}$ & $\begin{array}{c}2.135^{*} \\
(1.167)\end{array}$ & $\begin{array}{c}1.694 \\
(1.497)\end{array}$ & $\begin{array}{c}1.064 \\
(0.765)\end{array}$ & $\begin{array}{c}2.130 \\
(1.330)\end{array}$ & $\begin{array}{c}1.987 \\
(1.555)\end{array}$ & $\begin{array}{c}0.422 \\
(0.736)\end{array}$ & $\begin{array}{c}4.254 \\
(4.492)\end{array}$ & $\begin{array}{c}2.079 \\
(2.981)\end{array}$ & $\begin{array}{c}0.903 \\
(1.247)\end{array}$ \\
\hline $\begin{array}{l}\text { Model 3: Quadratic } \\
Y_{i, c, s}=\alpha+\tau T_{i, c, s}+\gamma\left(z_{i, c, s}-\bar{z}\right)+\phi\left(z_{i, c, s}-\bar{z}\right)^{2}+\varepsilon_{i, c, s}\end{array}$ & $\begin{array}{l}2.386^{* *} \\
(1.109)\end{array}$ & + & $\begin{array}{c}1.235 \\
(0.834)\end{array}$ & $\begin{array}{c}2.154^{*} \\
(1.204)\end{array}$ & + & $\begin{array}{c}0.582 \\
(0.784)\end{array}$ & $\begin{array}{c}3.968 \\
(4.502)\end{array}$ & $\begin{array}{c}2.300 \\
(3.875)\end{array}$ & $\begin{array}{c}1.063 \\
(1.200) \\
\end{array}$ \\
\hline $\begin{array}{l}\text { Model 4: Quadratic interaction } \\
\begin{array}{r}Y_{i, c, s}=\alpha+\tau T_{i, c, s}+\gamma\left(z_{i, c, s}-\bar{z}\right)+\delta\left(z_{i, c, s}-\bar{z}\right) \cdot T_{i, c, s}+\phi\left(z_{i, c, s}-\bar{z}\right)^{2} \\
+\lambda\left(z_{i, c, s}-\bar{z}\right)^{2} \cdot T_{i, c, s}+\varepsilon_{i, c, s}\end{array}\end{array}$ & $\begin{array}{l}2.119^{* *} \\
(0.951)\end{array}$ & + & $\begin{array}{c}0.924 \\
(0.560)\end{array}$ & $\begin{array}{c}1.958^{*} \\
(1.020)\end{array}$ & + & $\begin{array}{c}0.550 \\
(0.602)\end{array}$ & $\begin{array}{c}1.820 \\
(1.307)\end{array}$ & $\begin{array}{c}1.836 \\
(3.007)\end{array}$ & $\begin{array}{c}.016 \\
(1.038)\end{array}$ \\
\hline $\begin{array}{l}\text { Model 5: Quadratic interaction with covariates and school dummies } \\
\begin{aligned} Y_{i, c, s}=\alpha+\tau T_{i, c, s}+\gamma\left(z_{i, c, s}-\right. & \bar{z})+\delta\left(z_{i, c, s}-\bar{z}\right) \cdot T_{i, c, s}+\phi\left(z_{i, c, s}-\bar{z}\right)^{2} \\
& +\lambda\left(z_{i, c, s}-\bar{z}\right)^{2} \cdot T_{i, c, s}+\sum_{j=1}^{S-1} \beta^{j} X_{i, c, s}^{j}+\sum_{s=1} \zeta^{s} S D_{i, c, s}^{s} \\
& +\varepsilon_{i, c, s}\end{aligned}\end{array}$ & $\begin{array}{c}2.362^{*} \\
(1.253)\end{array}$ & + & $\begin{array}{c}0.692 \\
(0.583)\end{array}$ & $\begin{array}{l}1.608^{*} \\
(0.832)\end{array}$ & + & $\begin{array}{c}0.704 \\
(0.708)\end{array}$ & $\begin{array}{c}7.211 \\
(10.191)\end{array}$ & $\begin{array}{c}-27.798 \\
(74.926)\end{array}$ & $\begin{array}{c}-0.294 \\
(2.960)\end{array}$ \\
\hline Number of observations & 160 & 71 & 311 & 84 & 41 & 159 & 121 & 60 & 189 \\
\hline
\end{tabular}

This table represents the RD estimates using triangular kernel functions and different specifications of the functional form. The dependent variable is the growth rate of the math scores along the school year, standardized with mean zero and variance one, with respect to student's classroom. The assignment variable is the student age in months centered on the threshold value $\bar{z}: z_{-}(i, c, s)-144$. Thus, the value of the student age at the cutoff point becomes zero. The optimal bandwidth is chosen by Calonico et al. (2014) procedure. Robust standard errors are within parenthesis and are calculated as described by Calonico et al. (2017). ${ }^{* * *}, * *, *$ represent the statistical significance at the $1 \%, 5 \%$ and $10 \%$ levels, respectively. + There weren't enough observations to perform calculations. 
Due to the results presented in Table 2, the same estimations are conducted for the threshold age of 142 months, but no significance was found for the optimal bandwidth interval. Estimations are available upon request.

The evidences just presented demonstrate that students of the same age and with similar levels of mental development may display substantial differences in the improvement of their learning rate depending on the context in which they are inserted. In the case studied here, students of the control and treatment groups in the range of 11 years old display distinct improvement rates toward their academic performance over the school year, and the only difference directly observed is the fact that the treated ones belong to classes with older classmates. These results provide evidence that the age homogeneity policy, adopted in several Brazilian public schools, do not contribute to the improvement of learning, au contraire, students when allocated into more heterogeneous class in terms of age present a higher growth rate on math scores along the school year, than those assigned into homogenous age classrooms.

Our results contrast with the ones found by Koppensteiner (2018), possibly because his evidences do not clearly separate out the relative age effect from the peer effects. Students around the cutoff age are either the oldest or the youngest in their respective classes and, apart from the effect from being assigned to classes with different peer characteristics; there could be a separate pure relative age effect at work. Nevertheless, our identification strategy together with the outcome variable - which captures the growth and not only the level of the math performance, thus controlling for individual fixed effect - permit to overcome such issue and separate out own relative age effect from the peer age effects.

In this context, the peer effects identified here do not seem to operate directly through a better school performance in treatment classes compared to the control classes, since, in reality, the pupils allocated to younger classes present, on average, slightly higher math scores, as previously seen in Table 3. Possibly, the peer effects here have been acting in an indirect manner, through non-observable characteristics more developed in older peers, who, when interacting with the younger ones, tend to stimulate their cognitive aptitudes ${ }^{6}$. These sorts of results find support on the Rainbow Model proposed by Hoxby and Weingarth (2005), in which they claim students are better off when forced to deal with other types of peers provided someone understands deeply a subject when he/ she sees it approached from a variety of angles.

\section{Final Considerations}

This paper evaluates the influence of the classmates' age on the individual academic performance. The identification strategy explores a mechanism for the division of classes based on age homogeneity, with cutoff value determined by the Brazilian law of age at school entry.

Estimates based on fuzzy regression models demonstrate that being assigned to treated and older class increases by 2.34 sds the student's growth rate of math scores throughout the year, in comparison to those pupils allocated to classes with younger peers. We, thus, provide evidences that the age homogeneity policy, adopted in several Brazilian public schools, do not contribute to the improvement of learning, au contraire, students when allocated into more heterogeneous class in terms of age present a higher growth rate on math scores along the school year, than those assigned into homogenous age classrooms.

This study aggregates interesting evidence to the scarce literature on peer age effects, and provide results with direct policy implications. In countries, such as Brazil, with large educational inequalities in terms of grade-distortion, the debate about sorting students into more age heterogeneous classes is very relevant. Especially, considering that the costs of changing class composition in terms of age are virtually zero.

\section{Acknowledgements}

This work was supported by Fundação Joaquim Nabuco, a research institute from the Ministry of Education, Brazil.

\section{References}

[dataset] Fundação Joaquim Nabuco (FUNDAJ). (2013). Acompanhamento longitudinal do desempenho escolar de alunos da rede pública de ensino fundamental do Recife. Recife: FUNDAJ - Ministério da Educação.

[dataset] Instituto Nacional de Estudos e Pesquisas Educacionais Anísio Teixeira (INEP). (2013). Prova Brasil. Brasília: INEP - Ministério da Educação.

BRASIL. Ministério da Educação. (2008). Resolution CNE/CEB no. 4, February $20^{\text {th }} 2008$. Defines the operational guidelines for the first three grades of elementary education. Orientação sobre os três anos iniciais do Ensino

\footnotetext{
${ }^{6}$ This result finds a theoretical support through the concept of the Zone of Proximal Development (ZPD) proposed by Vygotski (1991). The author is a classical reference in the field of Social and Cognitive Psychology, and the ZPD concept relates to the difference between what a child can do without help and what he or she can do with help of a more experienced person (an adult, an older child or one with higher ease of learning, etc.).
} 
Fundamental de nove anos. Diário Oficial da União, Brasília, June $10^{\text {th }}$ 2008. Retrieved from: http://portal.mec.gov.br/cne/arquivos/pdf/2008/pceb004_08.pdf.

BRASIL. Ministério da Educação. (2010). Resolution CNE/CEB no. 6, October $20^{\text {th }}$ 2010. Defines the operational guidelines for enrolling students into elementary and childhood education. Diário Oficial da União, Brasília, October $21^{\text {st }} \quad 2010$, Section $1, \quad$ p. $17 . \quad$ Retrieved from: http://portal.mec.gov.br/index.php?option=com_docman\&view=download\&alias=15542-rceb006-10-pdf-1\&categ ory_slug $=$ abril-2014-pdf\&Itemid $=30192$

Calonico, S., Cattaneo, M. D., \& Titiunik, R. (2014). Robust nonparametric confidence intervals for regression-discontinuity designs. Econometrica, 82(6), 2295-2326. https://doi.org/10.3982/ECTA11757

Calonico, S., Cattaneo, M. D., Farrell, M. H., \& Titiunik, R. (2017). Rdrobust: Software for Regression Discontinuity Designs. The Stata Journal, 17(2), 372-404.

De Giorgi, G., Pellizzari, M., \& Woolston, W. G. (2010). Class size and class heterogeneity. NBER Working Paper 16405. https://doi.org/10.3386/w16405

Duflo, E., Dupas, P., \& Kremer, M. (2008). Peer effects, teacher incentives, and the impact of tracking: evidence from a randomized evaluation in Kenya. NBER Working Paper, 14475. https://doi.org/10.3386/w14475

Eisenkopf, G., Hessami, Z., Fischbacher, U., \& Heinrich, U. (2011). Academic performance and single-sex schooling: evidence from a natural experiment in Switzerland. CESifo working paper: Economics of Education, 3592.

Hahn, J., Todd, P., \& Van Der Klaauw, W. (2001). Identification and estimation of treatment effects with a regression-discontinuity design. Econometrica, 69(1), 201-209. https://doi.org/10.1111/1468-0262.00183

Hoxby, C., \& Weingarth, G. (2005). Taking race out of the equation: School reassignment and the structure of peer effects. Harvard University. Working Paper. Retrieved from: https://www.pausd.org/sites/default/files/pdf-faqs/attachments/TakingRaceOutOfTheEquation.pdf

Instituto Nacional de Estudos e Pesquisas Educacionais Anísio Teixeira (INEP). (2015). Censo da Educação Básica. Brasília: INEP - Ministério da Educação.

Koppensteiner, M. F. (2018). Relative age, class Assignment and academic performance: evidence from Brazilian primary schools. Scandinavian Journal of Economics, 120(1), 296-325. https://doi.org/10.1111/sjoe.12215

Lyle, D. S. (2009). The effect of peer group heterogeneity on the production of human capital at West Point. American Economic Journal: Applied Economics, 1(4), 69-84. https://doi.org/10.1257/app.1.4.69

Matta, R., Ribas, R. P., Sampaio, B., \& Sampaio, G. R. (2016). The effect of age at school entry on college admission and earnings: a regression-discontinuity approach. IZA Journal of Labor Economics, 5(9), 1-25. https://doi.org/10.1186/s40172-016-0049-5

McCrary, J. (2008). Manipulation of the running variable in the regression discontinuity design: a density test. Journal of Econometrics, 142(2), 698-714. https://doi.org/10.1016/j.jeconom.2007.05.005

Oosterbeek, H., \& Van Ewijk, R. (2014). Gender peer effects in university: evidence from a randomized experiment. Economics of Education Review, 38(C), 51-63. https://doi.org/10.1016/j.econedurev.2013.11.002

Ordine, P., Rose, G., \& Sposato, D. (2015). Early Enrollees and Peer Age Effect: First Evidence from INVALSI Data. Journal of Education and Training Studies, 3(2), 70-82. https://doi.org/10.11114/jets.v3i2.602

Prefeitura do Recife (2005). Metodologia de divisão do território do recife adotada no atlas municipal do desenvolvimento humano. In: Desenvolvimento humano no Recife - atlas municipal. Recife.

Sandgren, S., \& Strøm, B. (2005). Peer effects in primary school: Evidence from age variation. Paper presented at the 17th Annual congress of the European Economic Association, Venice, Italy. Retrieved from: http://old-hha.asb.dk/nat/nina/ncoe/papers0806/sandgren_strom.pdf

Schneeweis, N., \& Winter-Ebmer, R. (2007). Peer effects in Austrian schools. Empirical Economics, 32(2), 387-409. https://doi.org/10.1007/s00181-006-0091-4

Vardardottir, A. (2013). Peer effects and academic achievement: a regression discontinuity approach. Economics of Education Review, 36(C), 108-121. https://doi.org/10.1016/j.econedurev.2013.06.011

Vygotsky, L. (1991). Formação social da mente. São Paulo: Martins Fontes.

Xu, Y., \& Fan, L. (2018). Diverse friendship networks and heterogeneous peer effects on adolescent misbehaviors. Education Economics, 26 (3), 233-252. https://doi.org/10.1080/09645292.2017.1406458 
Zimmer, R. (2003). A new twist in the educational tracking debate. Economics of Education Review, 22(C), 307-315. https://doi.org/10.1016/S0272-7757(02)00055-9

\section{Copyrights}

Copyright for this article is retained by the author(s), with first publication rights granted to the journal.

This is an open-access article distributed under the terms and conditions of the Creative Commons Attribution license which permits unrestricted use, distribution, and reproduction in any medium, provided the original work is properly cited. 